\title{
Pengaruh Work Family Conflict Terhadap Job Involvement Studi Pada Perawat dan Bidan RSU X Dalam Rangka Meningkatkan Performa Kerja
}

\author{
Mieke Prasetyo \\ Program Magister Psikologi Profesi, Fakultas Psikologi \\ Universitas Padjadjaran \\ miekeprasetyo@gmail.com \\ Maya Rosmayati Ardiwinata \\ Program Magister Psikologi Profesi, Fakultas Psikologi \\ Universitas Padjadjaran \\ mayardiwi@gmail.com \\ Nurul Yanuarti \\ Program Magister Psikologi Profesi, Fakultas Psikologi \\ Universitas Padjadjaran \\ nurulyanuarti@yahoo.com
}

\begin{abstract}
Married nurses and midwives have double roles not only as an employee but also as a wife and a mother. Responsobilities on both roles have different characteristics. Their effort to fulfill each responsibility at the same time may cause conflicts. These work family confict may occur in some types, such as times based conflict, strain based conflict, and behavior based conflict. The consequences of the conflict occured will affect their jobs. The conflicts occured will affect nurses and midwives involvement in completion their assignments at hospital. Nurses and midwives who able to identify theirself on their job will result in their optimal work performance at hospital.

The study aims to discover whether there is an effect of Work Family Conflict on Job Involvement on nurses and midwifes at RSU X. Data collection on work family conflict variable based on modified and validated instrument from $S$. Carlson et.al (2000), and for job involvement variable based on modified quetionnaire from Lodhal dan Kejner (1965). Participants of the study were 65 respondents with characteristics such as woman, merried, and have a child.

Result of this study was work family conflicts, both in times based conflict, strain based conflict, and behavior based conflict, did not significantly effecting job involvement on nurses and midwives at RSU X. It showed that role conlicts on participants did not influence nurses and midwives involvement in completion of their assignments.
\end{abstract}

Keywords: nurses and midwives; work family conflict; job involvement 


\begin{abstract}
Abstrak
Perawat dan bidan yang telah menikah akan melakukan peran ganda sebagai seorang karyawan juga sebagai seorang ibu dan istri. Tuntutan peran pada area pekerjaan dan area keluarga memiliki karakteristik berbeda. Upaya untuk memenuhi tuntutan kedua peran dalam satu waktu sekaligus tidak menutup kemungkinan akan memunculkan konflik. Work Family Conflict ini dapat muncul dalam beberapa bentuk yaitu times based conflict, strain based conflict, dan behavior based conflict. Salah satu konsekuensi dari konflik ini adalah pada area pekerjaan. Konflik ini akan memengaruhi pada keterlibatan kerja perawat dan bidan dalam menyelesaikan pekerjaannya di rumah sakit. Perawat dan bidan yang mampu mengidentifikasikan diri pada pekerjaan akan memberikan performa kerja yang optimal di rumah sakit.

Penelitian ini bertujuan untuk mengetahui apakah ada pengaruh dari Work Family Conflict terhadap Job Involvement pada perawat dan bidan RSU X. Pengumpulan data pada variable work family conflict mengacu pada alat ukur yang telah dimodifikasi dan divalidasi oleh S. Carlson et.al (2000), sementara alat ukur variabel Job Involvement mengacu pada kuesioner yang telah dimodifikasi oleh Lodhal dan Kejner (1965). Penelitian dilakukan pada 65 orang responden dengan karakteristik karyawan tetap perempuan, telah menikah, dan memiliki anak.

Hasil penelitian menunjukkan bahwa Work Family Conflict, baik pada times based conflict, strain based conflict, dan behavior based conflict tidak signifikan memengaruhi Job Involvement pada perawat dan bidan RSU X. Hasil tersebut diketahui bahwa kondisi konflik peran yang dialami oleh responden tidak memberikan pengaruh pada keterlibatan perawat dan bidan dalam menyelesaikan pekerjaannya.
\end{abstract}

Kata kunci : perawat dan bidan; work family conflict; job involvement

\title{
Pendahuluan
}

Peran perempuan di dunia kerja saat ini mengalami peningkatan cukup pesat. Peran perempuan dulunya selalu diidentikkan dengan urusan domestik, seperti mengurus rumah tangga, suami, dan merawat anak. Seiring berkembangnya jaman dan gerakan emansipasi perempuan, peran perempuan sudah mulai tampak memberikan kontribusi pada bidang-bidang pekerjaan lainnya, misalnya saja peran perempuan di bidang industri, konstruksi, bahkan sampai politik. Tidak dipungkiri perempuan juga memberikan kontribusi baik pada kehidupan pribadi sebagai bentuk aktualisasi diri, membantu perekonomian 
keluarga, memberikan kontribusi pula bagi perekonomian nasional, dan kemajuan bangsa. Kondisi ini menunjukkan peran perempuan semakin profesional dalam berkarya dan berkontribusi dalam lingkungan kerja.

Berdasarkan data dari Badan Pusat Statistik (BPS) pada Februari 2017, Tingkat Partisipasi Angkatan Kerja (TPAK) pekerja perempuan di Indonesia meningkat sebesar $2,33 \%$ menjadi $55,04 \%$ dari sebelumnya yaitu, $52,71 \%$ pada Februari 2016. Hal ini menunjukkan perempuan semakin aktif mengambil bagian dalam mendukung perekonomian nasional dan memiliki kesempatan yang sama di bidang pekerjaan.

Perempuan yang bekerja utamanya yang telah menikah, secara tidak langsung memiliki dua peran sekaligus, yaitu peran sebagai karyawan dan peran ibu rumah tangga. Peran sebagai karyawan dengan tuntutan tugas yang harus diselesaikan secara tepat waktu, sesuai standar yang ditentukan, dan memiliki tanggung jawab atas pekerjaan, dan keberhasilan organisasi. Peran sebagai pengurus rumah tangga juga tak dapat di kesampingkan, yaitu untuk mengurus rumah, merawat anak dan melayani suami, serta tugas domestik lainnya.

Salah satu bidang pekerjaan yang banyak melibatkan perempuan adalah perawat dan bidan diantaranya adalah perawat dan bidan. Salah satu rumah sakit yang banyak memperkerjakan perawat dan bidan adalah RSU X. Perawat dan bidan adalah bagian dari rumah sakit yang berperan sebagai salah satu ujung tombak dalam memberikan pelayanan dituntut dapat selalu sigap, bekerja dengan cermat dan tepat dalam membantu pasien di rumah sakit. Pekerjaan menjadi perawat dan bidan juga dituntut untuk menguasai keterampilan khusus pada setiap layanan dan keterampilan mendukung lainnya seperti service excellent bagi pasien maupun keluarga pasien.

Perawat dan bidan yang kompeten merupakan salah satu aset penting yang dimiliki oleh sebuah rumah sakit. Seiring dengan perkembangan jaman, pandangan organisasi tentang karyawanpun berubah, dari yang memandang karyawan sebagai sumber daya (resources) yang dapat digunakan oleh organisasi untuk mencapai tujuan, menjadi modal (capital) penting bagi perusahaan untuk menjalankan, mengembangkan, dan mencapai tujuan organisasi secara optimal. 
Pandangan ini membuat karyawan dilihat memiliki potensi yang dapat memberikan keuntungan pada organisasi dan juga sebagai pemeran utama dalam menggunakan dan memanfaatkan segala sumber daya yang dimiliki organisasi (Ivanovic, Galicic, \& Krstevska, 2010).

Karyawan bidang keperawatan yang terdiri dari perawat dan bidan di RSU $\mathrm{X}$ merupakan komponen yang memiliki jumlah paling besar dibandingkan dengan jumlah karyawan lainnya. Jumlah karyawan bidang keperawatan yang berada di RSU X sebanyak 140 orang dari total karyawan 378 orang di bulan Maret 2019. Komposisi jumlah perawat dan bidan yang besar, tentunya harus mendapatkan perhatian lebih dari pihak manajemen, karena intensitas interaksi dengan pasien relatif lebih tinggi dibandingkan dengan petugas medis lainnya. Karyawan bidang keperawatan RSU X ini di dominasi oleh perempuan, jumlah karyawan bidang keperawatan berstatus karyawan tetap di RSU X pada bulan Maret 2019 terdiri dari 140 orang, dan 120 orang di antaranya adalah perempuan.

Munculnya konflik antara peran di area pekerjaan dan peran di area keluarga pada perawat dan bidan mungkin saja terjadi, dengan kondisi meningkatnya jumlah pasien dan bertambahnya beban kerja yang diterima serta tetap menjaga kualitas layanan yang diberikan, sisi yang lain perawat dan bidan memegang peran penting dalam keluarga. Selain itu di Indonesia, masyarakat masih mendudukkan perempuan sebagai mahluk yang dianggap perlu memegang peran utama dalam mengurusi tugas domestik, peran gender tradisional lebih dihargai oleh masyarakat ketimbang peran gender non tradisional (egalitarian) (Artiawati 2012).

Peran sebagai ibu dan istri memiliki tuntutan peran yang juga tidak dapat di kesampingkan, peran istri untuk mendampingi dan melayani suami, sebagai ibu untuk merawat dan memberikan kasih sayang pada anak sepanjang waktu, serta melakukan tugas domestik seperti membereskan rumah, memasak, dan memiliki peran untuk memberikan perhatian pada keluarga besar seperti pada saudara dan orang tua.

Konflik peran ganda ini dapat terjadi dari dua arah, yaitu peran pekerjaan mengganggu peran keluarga ataupun peran keluarga mengganggu peran 
pekerjaan. Tuntutan pekerjaan dan tugas-tugas yang ada dapat memberikan pengaruh terhadap peran di dalam keluarga. Perawat dan bidan mengerjakan tuntutan pekerjaan di rumah sakit untuk melayani pasien, berkoordinasi dengan rekan, maupun atasan. Tuntutan pekerjaan ini membutuhkan kesigapan dan ketepatan yang menguras energi dan menggunakan sebagian besar waktu sehingga, penyelesaian tugas rumah tangga, dan kualitas pertemuan untuk keluarga akan berkurang, hal ini menimbulkan rasa bersalah, tidak nyaman, dan kelelahan.

Perawat dan bidan yang memiliki tugas beragam baik dalam tugas asuhan keperawatan/kebidanan, menyelesaikan tugas administrasi, dan tugas lainnya dalam organisasi seperti kegiatan rutin mengikuti pelatihan, memberikan pendampingan pada perawat baru serta tugas lainnya di rumah sakit menyebabkan peran di keluarga menjadi terganggu. Kesibukan peran di rumah sakit menyebabkan perawat dan bidan kurang optimal saat menyelesaikan tugas dan tanggung jawab dikeluarga seperti bersantai bersama suami, menemani anak belajar dan bermain, serta mengurus urusan rumah tangga lainnya.

Menurut Greenhaus \& Beutell (1985), karyawan yang memiliki tanggung jawab yang tinggi di dalam keluarga dapat memicu timbulnya konflik yang berkaitan dengan pemenuhan tanggung jawab di dalam pekerjaannya. Semakin tinggi tanggung jawab yang dimiliki karyawan di dalam keluarga, maka potensi munculnya konflik akan semakin besar pula karena tanggung jawab dari kedua peran akan saling bertentangan dan saling menuntut satu sama lain. Tekanan muncul karena peran di dalam keluarga dan peran di dalam pekerjaan saling bersinggungan dan saling menuntut pemenuhan secara bersamaan. Kesulitan mengkombinasikan antara peran dalam pekerjaan dan rumah tangga serta pemenuhan tuntutan masing-masing peran tersebut mengakibatkan konflik peran.

Penelitian-penelitian yang berkaitan dengan pekerjaan biasanya banyak berfokus pada laki-laki, namun permasalahan dalam hal menggabungkan antara pekerjaan dan keluarga lebih banyak difokuskan pada wanita (Crawford \& Unger, 2004). Berbagai penelitian mengenai pemenuhan dua peran yang bertentangan secara konsisten menunjukkan bahwa kebanyakan perempuan yang bekerja 
mengalami konflik peran (Duxbury \& Higgins, 1991; Kinnunen \& Mauno, dalam Aycan \& Eskin, 2005). Nasir dan Nusi (dalam Almasitoh, 2011) menyebutkan dalam penelitiannya bahwa konflik peran ganda tidak akan terjadi jika ada keseimbangan antara peran dalam keluarga maupun pekerjaan. Namun, sangat sulit untuk mencapai keseimbangan antara peran sebagai istri dan peran sebagai seorang ibu dengan peran sebagai pencari nafkah

Penelitian mengenai hubungan kerja dan keluarga menjadi paradigma yang mendominasi dalam penelitian-penelitian sepanjang seperempat abad terakhir (Parasuraman \& Greenhaus, 1992). Semakin banyak peneliti mencurahkan energi mereka ke dalam penelitian tentang bagaimana seseorang mengelola dirinya sendiri untuk hidup dalam domain kerja dan domain keluarga pada saat yang sama. Pengelolaan diri pada dua domain atau lebih secara bersamaan dapat memunculkan ketegangan serta konflik peran yang berasal dari domain-domain tersebut.

Konflik peran yang terjadi didefinisikan oleh Khan et. al (1965 dalam J.G. Vallone, S.I Donaldson, 2001) :

"simultaneous occurence of two (or more) sets of role pressures such that compliance with one would make more difficult the compliance the other"

Konflik peran merupakan beberapa set dari tekanan peran terjadi pada saat bersamaan, pemenuhan pada satu peran menyulitkan seseorang untuk memenuhi perannya yang lain. Menurut teori peran, hipotesis kelangkaan menyebutkan bahwa individu memiliki besaran waktu dan energi yang konstan dan tetap, sehingga meningkatnya tuntutan peran cenderung meningkatkan kemungkinan konflik peran, role overload dan penyimpangan negatif (Chapman, IngersollDayton, \& Neal, 1994; Marks, 1977 dalam J.G. Vallone, S.I Donaldson, 2001).

Teori konflik peran pada area keluarga dan area pekerjaan disebut sebagai work family conflict yaitu teori yang dikembangkan oleh Greenhaus (1987) mengenai peran ganda tersebut. Menurut Greenhaus (1987) adalah bentuk dari konflik inter-role dimana terdapat tekanan dari area pekerjaan dan area keluarga yang sama-sama sulit untuk dipenuhi, maka keterlibatan dari peran dalam pekerjaan serta peran di keluarga tidaklah seimbang. 
Konflik ini hadir dalam dua arah : pekerjaan mengganggu peran keluarga (WIF) dimana tuntutan dari pekerjaan membuat individu kesulitan untuk melaksanakan tanggung jawab dalam keluarga dan keluarga menganggu peran pekerjaan (FIW) dimana tuntutan keluarga membatasi efektifitas pelaksanaan tanggung jawab pekerjaan. Meskipun kedua bentuk konflik ini cukup memberikan korelasi, tuntutan pekerjaan secara umum berasosiasi dengan work-family conflict, sedangkan tuntutan keluarga merupakan sumber proksimal pada work family conflict (Byron, 2005 dalam Korabik, Lero \& Whitehead; 2008). Pendekatan konseptual yang digunakan dalam beberapa kajian didasarkan pada premis bahwa WIF dan FIW merupakan dua bentuk konflik inter-role yang terpisah namun memiliki kaitan (Greenhaus \& Beutell, 1985; Kahn. 1981; Kahn, Wolfe, Quinn, Snoek \& Rosenthal, 1964; Pleck et. al., 1980 dalam Netemeyer, S. Boles \& Mc Murrian, 1996).

Greenhaus dan Beutell (1985) mengungkapkan bahwa terdapat 3 bentuk work-family conflict, yaitu : Time-based conflict (konflik berdasarkan waktu), Strain-based conflict (konflik berdasarkan ketegangan), serta Behavior-based conflict (konflik berdasarkan perilaku).

Keterlibatan karyawan dalam pekerjaan merupakan salah satu aspek yang juga menjadi perhatian dalam pengelolaan sumber daya manusia dalam organisasi. Lodhal dan Kejner melakukan penelitian mengenai Job Involvement serta berusaha untuk mengkonseptualisasikan dan mengoperasionalkannya. Penelitian tersebut memunculkan satu definisi bahwa Job Involvement adalah derajat dari seseorang menunjukkan performa kerja yang berdampak pada self esteem. Hasil penelitian ini sejalan dengan Allport (1947, dalam Mushawana 1998) sebuah deskripsi klasik mengenai ego seseorang sebagai daya tarik dari motif pencarian status pada pekerjaan.

Lawler \& Hall (1970), mengemukakan definisi Job Involvement :

"The degree to which a person perceives his total work situation to be an important part of his life and to be central to him and his identity because of the opportunity it affords him to satisfy his important need".

Definisi tersebut mengungkapkan bahwa job involvement merupakan 
tingkatan sejauh mana individu mempersepsikan seluruh situasi kerjanya sebagai bagian penting dalam hidupnya dan identitasnya karena hal tersebut memberikan kepuasan dalam memenuhi kebutuhannya.

Job involvement didefinisikan sebagai sejauh mana karyawan mengidentifikasikan dirinya dengan pekerjaannya secara psikologis, atau seberapa penting pekerjaan tersebut terhadap gambaran diri karyawan secara keseluruhan, dan sejauh mana kinerja karyawan memengaruhi self-esteem. Dari berbagai definisi di atas maka Job Invovement dapat disimpulkan bagaimana seseorang mengidentifikasikan dirinya terhadap pekerjaan, serta bagaimana pekerjaan itu bernilai bagi dirinya maupun harga dirinya dan tercermin pada partisipasi individu dalam pekerjaan.

Hazer dan Alvares (1981 dalam Lambert \& Paoline, 2012) menemukan bahwa job involvement bukanlah sebuah konsep statis yang dibentuk sebelum karyawan bergabung dalam suatu organisasi. Job involvement merupakan konsep dinamis yang dipengaruhi oleh faktor konstektual yang berhubungan dengan pekerjaan. Sesuai dengan perkembangannya, variabel-variabel yang berhubungan dengan job involvement digolongkan menjadi 2 faktor yaitu karakteristik individu dan karakterisktik pekerjaan.

\section{Metode}

Penelitian ini menggunakan pendekatan deduktif, yaitu suatu penelitian dimana prosesnya diawali dengan menurunkan hipotesis yang diperoleh dari beberapa teori dan pengamatan secara informal terhadap kejadian sehari-hari yang relevan dengan masalah penelitian. Pendekatan yang dilakukan dalam penelitian ini adalah ex post facto, yaitu mengamati dan mengumpulkan data dari sesuatu yang telah berlangsung (Kerlinger, 1990). Penelitian dilakukan secara empiris dan sistematik, dimana peneliti tidak memiliki kontrol langsung pada variabelvariabel bebas (independent variable) karena manifestasi fenomena telah terjadi atau karena fenomena sukar dimanipulasikan.

Populasi pada penelitian ini adalah seluruh perawat perempuan dan bidan yang ada di RSU X dengan karakteristik karyawan tetap, bekerja dengan sistem 
shift, sudah menikah dan memiliki anak. Populasi yang ada saat ini, sesuai dengan karakteristik adalah 65 orang dengan rincian 55 orang perawat dan 10 orang bidan. Sampel yang diambil adalah total samping sejumlah 65 orang.

Teknik pengumpulan data menggunakan skala pengukuran work family conflict dan job involvement dalam bentuk skala Likert. Alat ukur yang digunakan adalah kuesioner mengenai Work Family Conflict yang dikembangkan oleh Shinta Febrina (2016), menggunakan instrumen pengukuran yang telah dimodifikasi dan divalidasi oleh S. Carlson et al (2000). Alat ukur yang digunakan untuk mengukur variabel Job Involvement menggunakan kuesioner yang telah dimodifikasi dari Lodhal dan Kejner (1965).

Metode pengolahan data dalam penelitian ini adalah Analisis regresi sederhana berkenaan dengan studi ketergantungan suatu variabel, variabel terikat pada satu atau lebih variabel lain, variabel yang menjelaskan (explanatory variables), dengan maksud menaksir atau meramalkan nilai rata-rata hitung (mean) atau rata-rata populasi variabel tak bebas, dipandang dari segi nilai yang diketahui atau tetap (dalam pengambilan sampel berulang) variabel yang menjelaskan (Gujarati, 1999).

Analisis data dilakukan dengan menggunakan program SPSS 16 for Windows. Langkah pertama adalah mengubah skala data yang awalnya berskala ordinal menjadi data berskala interval dengan menggunakan MSI (Method Succesive Interval). Pengubahan ini dilakukan agar data yang diperoleh dapat dianalisis dengan menggunakan regresi linier sederhana. Selain melakukan suksesif data, terdapat beberapa uji asumsi yang juga harus dipenuhi sebelum melakukan analisis regresi. Uji asumsi dilakukan guna memperoleh model regresi dengan estimasi yang memiliki nilai akurasi yang dapat dipercaya atau tidak bias (Nawari, 2010).

\section{Hasil dan Pembahasan}

Uji validitas Work Family Conflict diperoleh nilai koefisien validitas antara 0.361- 0.745 pada taraf signifikant $\alpha=5 \%$, dan reliabilitas alat ukur Work Family Conflict diperoleh sebesar 0.857. Validitas Job Involvement diperoleh 
koefisien validitas antara 0.340-0.677 pada taraf signifiant $\alpha=5 \%$, sedangkan hasil uji reliabilitas alat ukur diperoleh hasil sebesar 0.873 .

Hasil uji hipotesis penelitian menunjukkan bahwa signifikansi (Sig.) sebesar 0.687, dengan demikian dapat dinyatakan bahwa $\mathrm{H}_{0}$ diterima dan $\mathrm{H}_{1}$ ditolak yang berarti tidak ada pengaruh Work Family Conflict terhadap Job Involvement. Uji hipotesis diketahui bahwa nilai $R$ Square untuk hipotesis sebesar 0.003, dengan demikian dapat dinyatakan bahwa kontribusi yang diberikan oleh variabel Work Family Conflict terhadap variabel Job Involvement dengan rumus $\mathrm{R}^{2}$ x $100 \%$ adalah sebesar $0.3 \%$, sedangkan $99.7 \%$ Job Involvement di pengaruhi oleh variabel lain yang tidak diteliti

Perawat dan bidan di RSU X merupakan salah satu ujung tombak dalam memberikan layanan bagi pasien dan keluarga pasien yang datang ke rumah sakit. Jumlah perawat dan bidan perempuan lebih banyak dibandingkan laki-laki dan sebagian besar telah menikah. Perawat dan bidan yang bekerja dan menikah memiliki tuntutan peran yang berbeda, satu sisi sebagai seorang karyawan yang dituntut dapat menyelesaikan tugas sebaik mungkin dan peran seorang istri dan ibu untuk mengurus kehidupan rumah tangga. Tuntutan peran ini tidak dapat dipungkiri akan muncul pada saat bersamaan dan dapat menyebabkan konflik peran. Konflik ini memungkinkan memberikan dampak pada pekerjaan maupun pada keluarga. Apabila dalam pekerjaan, akan menyulitkan individu dalam menampilkan performa kerja yang akan dicapai.

Peran pada area pekerjaan memiliki aturan yang jelas, jenis pekerjaan, job desc yang telah tersusun sedemikan rupa, mengatur hubungan dengan rekan, atasan dan juga instansi. Individu yang memiliki keterlibatan dalam pekerjaan akan mengeluarkan usaha untuk mencapai tujuan dari pekerjaan. Lodahl \& Kejner (1965) mendefinisikan Job Involvement yaitu sejauh mana karyawan mengidentifikasikan dirinya dengan pekerjaannya secara psikologis, atau seberapa penting pekerjaan tersebut terhadap gambaran diri karyawan secara keseluruhan, dan sejauh mana kinerja karyawan memengaruhi elf-esteemnya. Perawat dan bidan yang mengalami konflik peran, saat dihadapkan pada pemenuhan tututan peran secara bersamaan diasumsikan akan memberikan pengaruh pada area 
pemenuhan tuntutan pekerjaan.

Uji hipotesis atas kedua variabel penelitian diketahui bahwa Work Family Conflict tidak berpengaruh terhadap Job Involvement. Hasil uji hipotesis bahwa Work Family Conflict tidak memberikan pengaruh secara signifikan pada Job Involvement pada perawat dan bidan, adanya pertentangan dari dua tuntutan pemenuhan peran sebagai seorang perawat dan bidan dan seorang ibu dan istri yang dialami oleh responden memengaruhi bagaimana seorang perawat dan bidan mengidentifikasikan diri pada pekerjaan, serta nilai pekerjaan bagi diri dan harga diri yang tercermin pada partisipasi individu dalam pekerjaan.

Konflik peran yang dirasakan oleh perawat dan bidan dalam memenuhi tuntutan peran dalam kehidupan sehari-hari tidak memengaruhi responden dalam menyelesaikan tugas dalam bekerja. Hal ini menunjukkan bahwa perawat dan bidan yang mengalami konflik peran dapat merespon pekerjaan yang diberikan kepadanya tanpa dipengaruhi oleh rasa cemas, rasa khawatir, dan tidak nyaman dengan adanya konflik peran yang dialami. Konflik peran ini tidak memberikan pengaruh pada perilaku perawat dan bidan saat memberikan respon ketika menerima tugas yang diberikan.

Konflik peran yang mengakibatkan adanya keterbatasan waktu dalam menyelesaikan peran di rumah dan ditempat kerja tidak berpengaruh ketika perawat dan bidan menunjukkan keterlibatan mereka dalam bekerja untuk meluangkan waktunya berfikir tentang pekerjaan sekalipun mereka tidak sedang bekerja. Selain itu rasa cemas dan rasa lelah yang dihadapi oleh responden akan konflik peran yang sedang dialami tidak memberikan pengaruh tenaga untuk meluangkan waktunya memikirkan pekerjaan dan mampu memusatkan pikirannya pada pekerjaan sekalipun dihadapkan pada situasi yang sulit. Sekalipun dihadapkan pada konflik peran antara pekerjaan dan keluarga, perawat dan bidan merasa tidak nyaman ketika gagal dalam pekerjaan sehingga akan terus berusaha untuk menunjukkan hasil kerja.

Rasa cemas, khawatir dan rasa bersalah yang dirasakan karena adanya Work Family Conflict yang dialami dalam menyeimbangkan antara peran sebagai ibu dan istri serta peran sebagai perawat dan bidan tidak memberikan pengaruh 
untuk bertanggung jawab dalam menyelesaikan pekerjaan utamanya saat memberikan asuhan kepada pasien dan keluarga pasien. Selain itu, konflik peran ini juga tidak memengaruhi sikap perawat dan bidan untuk menyelesaikan pekerjaan seperti kedispilinan untuk menyelesaikan tugas tepat waktu, mematuhi aturan yang telah ditetapkan, dan kesediaan untuk bekerja lembur dalam menyelesaikan tugas yang diberikan.

Perawat dan bidan yang merasakan kesulitan dalam mengatur waktu antara keluarga dan pekerjaan, sering kali merasa kelelahan, dan adanya tuntutan yang berbeda dari peran sebagai seorang perawat dan bidan untuk memberikan service excellent pada pasien dan peran sebagai seorang ibu untuk memberikan perhatian pada suami dan anak serta dalam menyelesaikan tugas sehari-hari tidak memberikan pengaruh pada keterlibatan perawat dan bidan dalam bekerja di RSU X. Adanya kondisi tersebut tidak memberikan pengaruh pada intensitas kehadiran dan penyelesaian tugas-tugas yang dilakukan oleh perawat dan bidan.

Salah satu antesenden dari Job Involvement menunjukkan bahwa pekerjaan yang dapat menimbulkan keterlibatan adalah pekerjaan yang bervariasi (job variety), memiliki otonomi yang tinggi, dan identitas tugas yang jelas (task identity). Job Variety merupakan derajat variasi dari pekerjaan (Price \& Mueller, 1986 dalam Lambert \& Paoline, 2012). Konflik yang dialami oleh perawat dan bidan seperti rasa cemas, khawatir, tidak nyaman, dan rasa bersalah yang dirasakan akibat adanya konflik peran ini tidak memengaruhi keterlibatan perawat dan bidan dalam bekerja. Sejauh ini dengan konflik yang dirasakan oleh perawat dan bidan terhadap dua peran ini tidak memengaruhi bagaimana karyawan mulai dari merespon pekerjaan yang diberikan, cara mengekspresikan keterlibatan mereka dalam bekerja, rasa bertanggung jawab dan disiplin dalam menyelesaikan pekerjaan, serta sikap perawat dan bidan untuk menghindari ketidakhadiran dan perasaan bersalah ketika belum menyelesaikan pekerjaan.

Perempuan yang bekerja dan telah menikah tidak dapat dipungkiri akan menghadapi tuntutan peran yang berbeda dalam satu waktu sekaligus. Peran sebagai karyawan yang dituntut menyelesaikan tugas sesuai standar yang telah yang ditentukan dan peran sebagai seorang istri dan ibu yang bertanggung jawab 
melayani suami, mengasuh anak dan menyelesaikan tugas rumah tangga lainnya. Times Based Conflict ini dapat terjadi karena waktu yang digunakan untuk memenuhi satu peran mengakibatkan sulitnya pemenuhan tanggung jawab dari peran lainnya. Artinya dalam satu waktu, individu hanya dapat memenuhi tuntutan dari salah satu peran yang dimilikinya. Tuntutan dari dua peran sekaligus ini akan memunculkan rasa bersalah, cemas, dan khawatir pada diri perawat dan bidan.

Konflik peran berkaitan dengan waktu karena adanya tuntutan sebagai seorang ibu yang juga memiliki tanggung jawab untuk merawat anak dan melakukan kegiatan rumah tangga lainnya tidak memberikan pengaruh saat perawat dan bidan melakukan pekerjaan. Perawat dan bidan dapat merespon positif dan menerima tugas yang diberikan. Konflik ini tidak memberikan pengaruh saat perawat dan bidan mengekspresikan keterlibatan pada pekerjaan seperti saat memberikan asuhan keperawatan pada pasien. Kondisi perawat dan bidan dengan tututan sebagai pengurus rumah tangga dan karyawan yang tidak dapat dipisahkan, tidak memengaruhi perawat dan bidan untuk bertanggungjawab menyelesaikan tugas yang telah diberikan kepadanya dan bersikap disiplin untuk mengerjakan tugas sesuai dengan aturan yang telah ditetapkan.

Tuntutan untuk menampilkan performa terbaik saat bekerja, menyelesaikan tugas yang diberikan, memberikan respon yang positif terhadap tugas tidak dipengaruhi oleh konflik peran berdasarkan waktu. Tampilan kerja yang ditunjukkan saat ini tidak dipengaruhi oleh times based conflict yang yang sedang dialami oleh karyawan. Perawat dan bidan yang mengalami konflik berdasarkan waktu ini telah menyadari bahwa memilih profesi sebagai perawat dan bidan harus menyediakan waktu memberikan layanan 24 jam. Peran dukungan sosial untuk menghadapi situasi pemenuhan peran dalam waktu yang bersamaan dan manajemen waktu yang dimiliki mengelola konflik keluarga dan pekerjaan. Tuntutan pemenuhan peran antar perilaku kedua peran tersebut dinilai sebagai situasi yang tidak menimbulkan keterlibatan pekerjaan sebagai perawat dan bidan.

Tuntutan peran yang saling bersinggungan ini sebagai seorang karyawan, 
utamanya perawat dan bidan dapat memberikan pengaruh baik pada diri secara pribadi atau keluarga maupun pada pekerjaan. Berdasarkan uji hipotesis yang dilakukan maka diketahui bahwa Strain Based Conflict tidak berpengaruh terhadap Job Involvement Perawat dan bidan RSU X. Makna dari hipotesis ini adalah bahwa konflik peran yang didasari oleh adanya ketegangan akan adanya dua peran baik sebagai sebagai karyawan dan peran sebagai ibu dan istri tidak memberikan pengaruh pada keterlibatan karyawan saat bekerja.

Ketegangan dan rasa cemas yang dirasakan oleh perawat dan bidan akan konflik peran ini tidak memberikan pengaruh saat merespon tugas yang diberikan saat bekerja. Perawat dan bidan dalam menyelesaikan tugas sehari-hari utamanya dalam memberikan asuhan keperawatan pada pasien dan keluarga pasien tidak dipengaruhi oleh kondisi dari konflik peran yang dialami. Strain based conflict ini juga tidak memberikan pengaruh pada kesigapan karyawan saat melakukan tugas ditempat kerja. Rasa tanggung jawab serta kedispilinan saat bekerja tidak dipengaruhi oleh strain based conflict yang sedang dialami oleh karyawan. Selain itu, konflik peran ini juga tidak memberikan pengaruh ketika karyawan dituntut untuk memberikan perhatian dan memusatkan perhatian pada pekerjaan yang sedang dilakukan.

Ada kalanya konflik ini memunculkan rasa lelah baik secara emosi dan fisik saat dihadapkan pada situasi pemenuhan peran sebagai seorang tenaga medis yang dituntut selalu sigap dan tidak mudah mengeluh saat bertemu dengan pasien serta, sebagai ibu atau istri yang juga perlu memberikan perhatian dan kasih sayang pada keluarga. Perawat dan bidan yang telah memilih menjalankan profesi ini telah mengetahui bahwa akan menghadapi situasi terkait beban kerja dan resiko-resiko yang dihadapi sehingga perawat berusaha mengelola hal tersebut sehingga tidak memberikan dampak pada keterlibatan dalam pekerjaan di rumah sakit.

Behavior Based Conflict tidak berpengaruh terhadap Job Involvement pada perawat dan bidan, kondisi ini bermakna bahwa konflik peran berdasarkan perilaku tidak memberikan pengaruh terhadap keterlibatan karyawan saat bekerja. Merupakan konflik yang muncul ketika perilaku yang ditampilkan dalam satu 
peran tidak sesuai dengan ekspektasi perilaku pada peran lain tidak berpengaruh pada sejauh mana perawat dan bidan mengidentifikasikan diri mereka terhadap pekerjaan dibidang keperawatan. Tuntutan peran untuk menampilkan perilaku yang tentunya berbeda antara menjadi ibu dan menjadi perawat dan bidan tidak memengaruhi antusiasme dan sikap saat merespon pekerjaan yang diterima. Tampilan kerja dan penilaian diri atas kerja yang ditunjukkan saat ini tidak dipengaruhhi oleh konflik peran berdasarkan perilaku yang dialami oleh karyawan.

Profesi perawat dan bidan memiliki karakteristik yaitu keharusan untuk menampilkan kepedulian, kasih sayang, siap membantu, memberikan harapan yang memadai, komitmen dan memperhatikan kebutuhan pasien. Aspek ini juga sejalan dengan perilaku yang biasa ditampilkan seorang ibu dan istri. Seorang ibu dituntut untuk berkomitmen dalam memenuhi kebutuhan suami dan ank-anaknya, sama halnya dengan perilaku yang ditampilkan sebagai seorang perawat dan bidan di rumah sakit.

Sebagai ibu diharuskan untuk menunjukkan kasih sayang dan kepedulian bagi anak-anaknya. Disisi lain adapun perbedaan ekspektasi perilaku yang terlihat yaitu perawat dan bidan diharapkan dapat mengendalikan amarah atau perasaan kesal terhadap pasien dan keluarga pasien sedangkan orang tua ada kalanya bersikap tegas dan memarahi anak dalam rangka mendidik. Perbedaan tuntutan perilaku antar kedua peran tersebut dinilai sebagai situasi yang tidak menimbulkan pengaruh pada Job Involvement perawat dan bidan.

\section{Kesimpulan Dan Saran}

\section{Kesimpulan}

Work Family Conflict tidak berpengaruh pada Job Involvement pada Perawat dan Bidan RSU X. Konflik peran yang dialami oleh perawat dan bidan saat ini tidak memberikan pengaruh pada keterlibatan karyawan saat bekerja sebagai perawat dan bidan RSU X. Gambaran work family conflict perawat dan bidan RSU X diketahui bahwa sebagian besar mengalami konflik peran pada kategori moderat. Kondisi ini menunjukkan bahwa sebagian besar perawat dan 
bidan mengalami dan merasakan konflik peran dalam kehidupan mereka, adanya tuntutan peran dikeluarga dan tuntutan peran pekerjaan yang saling bertentangan namun cenderung tidak berdampak signifikan pada partisipasi peran dikeluarga maupun dipekerjaan. Gambaran job involvement perawat dan bidan RSU X diketahui sebagian besar pada kategori moderat. Perawat dan bidan cukup terlibat pada pekerjaan, dapat mengidentifikasi diri dengan pekerjaan secara psikologis, pekerjaan cukup menjadi gambaran dari diri meskipun belum sepenuhnya tercermin pada partisipasi individu dalam pekerjaan.

\section{Saran}

Mengingat tidak ada pengaruh dari variabel ini, maka disarankan untuk mempertimbangkan variabel lain yang menjadi konsekuensi dari Work Family Conflict bisa pada area individu maupun kepuasan dalam keluarga. Untuk lebih memahami dinamika yang terjadi, maka disarankan untuk mempertimbangkan variabel lain seperti coping stress, nilai karakteristik individu dijadikan sebagai variabel mediator sehingga peneliti mendapatkan pemahaman yang lebih komprehensif.

\section{DAFTAR PUSTAKA}

Almasitoh, U. H. (2011). Stres Kerja Ditinjau dari Konflik Peran Ganda dan Dukungan Sosial pada Bidang keperawatan. Psikoislamika, Jurnal Psikologi Islam no 8 63-82

Artiawati. (2012). Konflik Kerja Keluarga pada Jurnalis di Jawa dan Bali (Model Konflik) kerja-Keluarga dengan ideologi peran gender, beban kerja berlebih, dukungan sosial dan kepribadian sebagai antesenden; rasa bersalah dan kesejahteraan psikologis sebagai konsekuensi. Disertasi. Tidak diterbitkan. Program Pascasarjana. Universitas Padjadjaran. Bandung

Carlson, D. L., Kacmar, K. M., Williams, L. L. (2000). Construction and Initial Validation of a Multidimensional Measure of Work-Family Conflict. Journal of Vocational Behavior 56, 249-276

Crawford, Mary and Unger, Rhoda. (2004). Women and Gender : A Feminist 
Psychology. New York : The McGraw-Hill Companies. Inc

Greenhaus, J. H., Bedeian, A. G., \& Mossholder, K. W.(1987). Work experiences, job performance, and feelings of personal and family well-being. Journal of Vocational Behavior, 31, 200-215.

Greenhaus, J.H., Beutell, N.J. (1985) Sources of conflict between work and family roles. Academy of Management Review 10:76-88

Greenhaus, J.H., Parasuraman.(1989). Sources of Work Family Conflict among Two Career Couples. Journal of Vacational Behavior. Vol 34. 133153

Gujarati, Damodar. (2003).Ekonometrika Dasar. Jakarta : Erlangga

Ivanovic.S., Galicic. V., Krstevska. M. (2010). Event Planning as a Fuction InThe Hospitality Industry, Journal Tourism \& Hospitality Management 925-930

J.G Vallone, I. Donalson. (2001). Consequences of Work Family Conflict on Employee Well Being Over Time. Journal of Work and Stress.214-226

Karlinger, F.M.E.J. (2008). Korelasi dan Analisa Korelasi Regresi Ganda. Yogyakarta : Nur Cahya

Lawler, E., \& Hall, D. (1970). Relationship of job characteristics to job involvement, satisfaction, and intrinsic motivation. Journal Of Applied Psychology, 54(4), 305-312. http://dx.doi.org/10.1037/h0029692

Lodahl, T., \& Kejnar, M. (1965). The definition and measurement of job involvement. Journal Of Applied Psychology, 49(1), 24-33.

Mushawana. S.E. (1998) .The Job Involvement and Job Satisfaction of Traffic Officer and bus Drivers. Thesis. Not Publish Rand Africaans University

Nawari. (2010). Analisis Regresi dengan MS Excel 2007 dan SPSS 17. Jakarta : PT Elex Media Komputindo.

Netemeyer.S., Boles, Mc Murrian. (1996). Development and Validation of Work Family Conflict and Family Work Conflict scales. Journal of Applied Psychology 400-410 